\title{
Case study on the clinical and anatomopathological descriptions of dog with primary
}

\section{uveal lymphoma}

\author{
Estudo de caso sobre as descrições clínicas e anatomopatológicas de cão com linfoma uveal \\ primário
}

Estudio de caso sobre las descripciones clínicas y anatomopatológicas de un perro con linfoma uveal primario

Fernanda Gosuen Gonçalves Dias ORCID: https://orcid.org/0000-0001-6072-4789

E-mail: fernandagosuen@yahoo.com.br

Larissa Fernandes Magalhães

ORCID: https://orcid.org/0000-0002-0986-2083

University of Franca, Brazil

E-mail: lala.fm@hotmail.com

Lucas de Freitas Pereira

ORCID: https://orcid.org/0000-0001-6611-296X University of Franca, Brazil

E-mail: lucapereira@gmail.com

Cristiane dos Santos Honsho

ORCID: https://orcid.org/0000-0002-5307-8552

University of Vila Velha, Brazil

E-mail: cristiane.honsho@uvv.br

Marina Laudares Costa

ORCID: https://orcid.org/0000-0002-3895-3523 University of Franca, Brazil

E-mail: marinalaudares@hotmail.com

Alex Roberto de Oliveira

ORCID: https://orcid.org/0000-0002-6726-5498 University of Franca, Brazil

E-mail: alexr_medvet@hotmail.com

Daniela do Nascimento Belmiro ORCID: https://orcid.org/0000-0002-5060-8095 University of Franca, Brazil

E-mail: dany0210@outlook.com.br

Victória Marques Russo Ramos

ORCID: https://orcid.org/0000-0003-4876-1020 University of Franca, Brazil

E-mail: victoriamrussoramos120@gmail.com

Adriana Torrecilhas Jorge

ORCID: https://orcid.org/0000-0001-8518-1311

Self-employed veterinary doctor, Brazil

E-mail: adrianatjorge@hotmail.com

\begin{abstract}
Intraocular lymphoma is a malignant neoplasm, which commonly affects the uveal tract of dogs, most of the time, a consequence of the multicentric by the hematogenous spread of neoplastic lymphocytes. The symptoms are varied and the chronicity can cause serious eye problems such as glaucoma and loss of visual acuity. In view of the unusual occurrence of primary ocular lymphoma in dogs, the objective was to discuss the case of a dog with uveal involvement, presenting conjunctival congestion, increased episcleral vessels, hypopyon, hyphema and increased intraocular pressure. After seven days of conservative treatment, symptoms worsened, especially the intraocular pressure. The tutor returned only two months after the consultation with the sonographic report of neoplasia in the uvea. There was an increase in the ocular bulb, vascularization and corneal edema, posterior synechia, discomfort, loss of visual acuity and neoformation in the iris. Was opted for enucleation and the histopathology suggested large cell lymphoma in the uveal tract. Two years after surgery, no metastases were observed. It is concluded that lymphoma can affect the uveal tract primarily in dogs, demonstrating different clinical signs and, in addition, early diagnosis and correctly instituted treatment favor quality of life and survival of the affected.
\end{abstract}

Keywords: Canine; Intraocular lymphosarcoma; Veterinary ophthalmology; Uvea. 


\section{Resumo}

O linfoma intraocular é uma neoplasia maligna que comumente afeta o trato uveal de cães, sendo na maioria das vezes, consequência da forma multicêntrica pela disseminação hematogênica de linfócitos neoplásicos. Os sintomas são variados e a cronicidade pode causar graves problemas oculares, como glaucoma e perda da acuidade visual. Perante a ocorrência incomum do linfoma primário ocular em cães, o objetivo foi discorrer o caso de uma cadela com comprometimento uveal, apresentando congestão conjuntival, aumento de vasos episclerais, hipópio, hifema e aumento da pressão intraocular. Após sete dias de tratamento conservador, observou-se piora especialmente na pressão intraocular. O tutor retornou somente após dois meses da consulta com o laudo ultrassonográfico de neoplasia na úvea. Notou-se aumento do bulbo ocular, vascularização e edema corneal, sinéquia posterior, desconforto. perda da acuidade visual e neoformação em íris. Optou-se pela enucleação e a histopatologia sugeriu linfoma de grandes células no trato uveal. Após dois anos da cirurgia não foi observado metástases. Conclui-se que o linfoma pode acometer o trato uveal de forma primária, demonstrando sinais diversos e, além disso, o diagnóstico precoce e o tratamento corretamente instituído favorecem a qualidade de vida e sobrevida do acometido.

Palavras-chave: Canino; Linfossarcoma intraocular; Oftalmologia veterinária; Úvea.

\section{Resumen}

El linfoma intraocular es una neoplasia maligna que comúnmente afecta el tracto uveal de los perros, siendo más a menudo una consecuencia de la forma multicéntrica por diseminación hematógena de linfocitos neoplásicos. Los síntomas son variados y la cronicidad puede provocar problemas oculares graves, como glaucoma y pérdida de la agudeza visual. Dada la infrecuente aparición de linfoma ocular primario en perros, el objetivo fue discutir el caso de una perra con afectación uveal, que presenta congestión conjuntival, aumento de vasos epiesclerales, hipopio, hipema y aumento de la presión intraocular. Después de siete días de tratamiento conservador, se observó un empeoramiento especialmente en la presión intraocular. El tutor regresó solo dos meses después de la consulta con el informe ecográfico de neoplasia de úvea. Hubo aumento del globo ocular, vascularización y edema corneal, sinequia posterior y malestar. pérdida de agudeza visual y neoformación del iris. Se eligió la enucleación y la histopatología sugirió linfoma de células grandes en el tracto uveal. Dos años después de la cirugía, no se observaron metástasis. Se concluye que el linfoma puede afectar principalmente a la vía uveal, presentando diferentes signos y, además, el diagnóstico precoz y el tratamiento correctamente instituido favorecen la calidad de vida y supervivencia de la persona afectada.

Palabras clave: Canino; Linfosarcoma intraocular; Oftalmología veterinaria; Uvea.

\section{Introduction}

The eye is considered a sensory organ, composed of several structures that associated provide the emission and reflection of light for the formation of images and visual acuity of animals (Hesse et al., 2015).

The eyeball is composed of the fibrous (sclera, limbus and cornea), nervous (retina and optic nerve) and vascular (uveal tract) tunics. In this context, the uveal tract (uvea), formed by the iris, ciliary and choroidal body, is highly vascularized (Oriá et al., 2015), providing part of the blood supply to the nerve tunic, being essential in maintaining the blood-eye barrier (Labelle \& Labelle, 2013; Maggs et al., 2013).

The iris regulates the amount of light that enters the posterior portions of the eyeball, providing the perception of visual depth of field for nearby objects and reduction of optical aberrations caused by the peripheral lens (Conceição et al., 2010; Gelatt et al., 2013). Located posterior to the iris, the ciliary body has the function of supporting the lens (Dubielzig, 2002; Maggs et al., 2013). The choroid extends to the optic nerve, providing a supply for the rods and cones (Escanilla et al., 2012).

The eye neoplasms can cause inflammation, pain, secondary glaucoma, changes in vision and, in more severe cases, loss of the eye bulb (Conceição et al., 2010; Malho et al., 2013). Malignant neoplasms have undifferentiated cells, degree of rapid evolution and ability to spread to adjacent tissues (Hesse et al., 2015; Oriá et al., 2015; Machado et al., 2021; Mota et al., 2021).

Among the primary intraocular neoplasms most commonly diagnosed in dogs, there are melanoma, adenoma, adenocarcinoma and osteosarcoma, originating from the iris, ciliary body or choroid. The secondary ones result from distant 
metastases and can compromise the uveal tract and other ocular or facial structures, being the lymphoma, carcinoma, adenocarcinoma and transmissible venereal tumor the most common (Grahn et al., 2006; Oriá et al., 2015).

In this sense, intraocular lymphoma (or lymphosarcoma) is characterized as malignant, originating in solid, rapidly growing lymphoid organs, usually secondary in character (Wiggans et al., 2014; Rodriguez et al., 2017; Lanza et al., 2018) and common occurrence in the canine species, representing 5 to $10 \%$ of all neoplasms (Conceição et al., 2010; Escanilla et al., 2012; Hesse et al., 2015; Oriá et al., 2015).

Given the importance of ocular neoplasms in impairing visual acuity and the unusual occurrence of primary ocular lymphoma in small animals, the objective of the present work was to report the case of a dog with this type of neoplastic in the uveal tract and, nevertheless, to emphasize the clinical signs, means of diagnosis, therapeutic protocol and prognosis.

\section{Methodology}

The methodology was based on a qualitative case study (Pereira et al., 2018), with data collected from a real event, with the objective of describing details regarding the symptoms, forms of diagnosis, therapeutic options and prognosis of a ocular neoplastic disease of uncommon occurrence in the canine species (Hesse et al., 2015; Oriá et al., 2015).

Although rare in dogs, primary uveal lymphoma can cause changes in visual acuity and, given its severity, it should be included in the differential diagnosis of other ocular malignancies in dogs (Lanza et al., 2018); thus, the information provided in this work will allow a better quality of life and survival of affected patients.

Initially, as a methodological referral, a bibliographic survey was used, considering the last twenty-two years (2000 2022) of scientific literature for later comparison with the reported patient data.

\section{Case study}

It was attended at the Veterinary Ophthalmology Sector of the University of Franca (UNIFRAN), a dog, female, mixed breed, neutered, six years old, with a history of a reddish left eye for two days. On the left ophthalmological examination, marked conjunctival congestion, increase in episcleral vessels, hypopyon and mild hyphema were observed (Figure 1).

The Schirmer's tear test, performed for the inserting a strip of commercial sterile millimeter filter paper (Tear Flo ${ }^{\mathrm{TM}}$ Diagnostic Test Strips $^{\circledR}$ ) in the conjunctival fornix, in the middle third of the left lower eyelid, for 60 seconds, it did not indicate quantitative changes in the lacrimal production. Intraocular pressure, measured with a portable applanation tonometer (Tono-Pen Avia $^{\mathrm{TM}}{ }^{\circledR}$ ), after corneal anesthetic desensitization with $0.5 \%$ proximetacaine hydrochloride eye drops (Anestalcon colírio ${ }^{\circledR}$ Alcon Laboratórios do Brasil Ltda, São Paulo - SP), was increased (27 mmHg). The corneal dyeing test, using sodium fluorescein strips 1\% (Ophthalmos Ltda, Jabaquara - SP) was negative. 
Figure 1: Left eye of a dog with conjunctival congestion and an increase in episcleral vessels (*), hypopyon (white arrow) and discreet hyphema (red arrow).

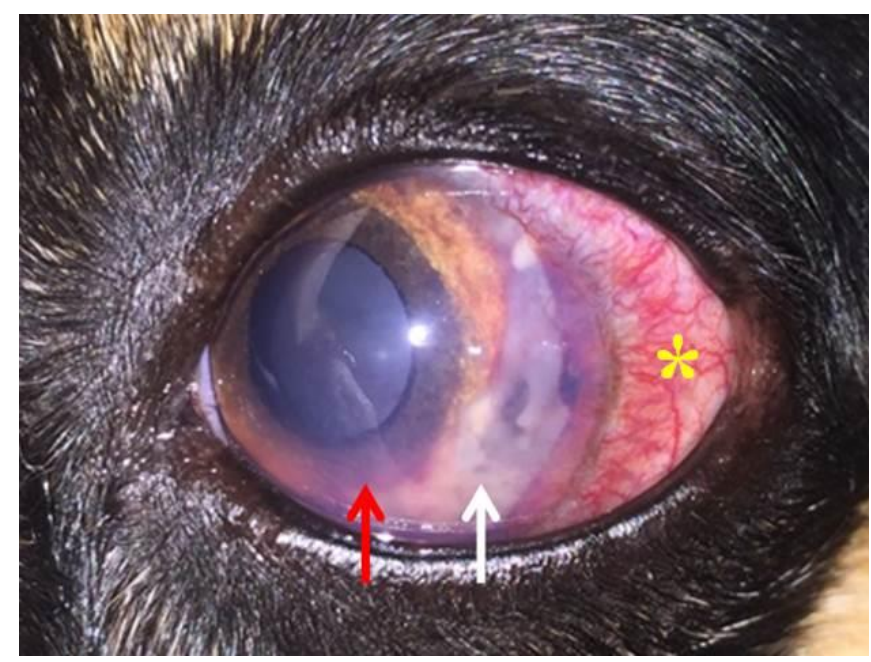

Fonte: Arquivo pessoal (2019).

The palpation of regional lymph nodes did not show changes in terms of size, consistency, mobility, temperature and sensitivity. Hematological tests were within the normal range for the species; chest x-rays showed no evidence of pulmonary metastasis, nor did ultrasound exclude abdominal nodules.

The initial diagnostic suspicion was ocular inflammation or neoplasia in the left uveal tract. Prednisolone acetate eye drops were prescribed (Predfort ${ }^{\circledR}$ - Allergan Produtos Farmacêuticos Ltda, São Paulo - SP: one drop in the left eye, every four hours, for seven consecutive days), dorzolamide hydrochloride (Ocupress ${ }^{\circledR}$ - União Química Farmacêutica Nacional S/A, Embu-Guaçu - SP: one drop in the left eye, every 12 hours, for seven days) and ocular ultrasound was requested.

After the 7th day of conservative treatment, there was a worsening in the left eye clinical symptoms (Figure 2), including intraocular pressure $(30 \mathrm{mmHg})$; however, for financial reasons, the tutor had not yet authorized the performance of ocular ultrasound. Thus, the topical treatment was maintained for another seven consecutive days.

The tutor did not attend the return visit and, after two months, the patient presented worsening of the ocular clinical signs, which included an increase in the eyeball, increased episcleral vessels with marked conjunctival congestion, vascularization and corneal edema, posterior synechia and visualization of neoformation in the iris (Figure 3), in addition to discomfort and loss of visual acuity. The ultrasound examination revealed an increase of $0.12 \mathrm{~cm}$ in the anterior chamber, in addition to an oval image in the left uveal tract, measuring approximately $1.31 \mathrm{~cm} \times 0.51 \mathrm{~cm}$, with irregular contours (Figure 4), heterogeneous aspect, being suggestive of neoplasia.

Enucleation was performed using the conventional subconjunctival technique (Martin et al., 2013).

The left eye bulb was sent to the Histotechnology Laboratory at the University of Franca for histopathology and, after routine preparation of the material and staining in hematoxylin-eosin (HE) (Carson \& Hladik, 2009), the examination showed neoplastic proliferation of lymphocytes in the sclera, surrounding the entire circumference of the posterior chamber and in the region of the left uveal tract. The cells had a solid arrangement, sometimes forming nests separated by bundles of connective tissue and the presence of melanocytes interspersed with proliferation. Neoplastic cells had a high nucleus-cytoplasm ratio, moderate cell pleomorphism, scarce cytoplasm and vesicular nucleus with evident nucleoli, predominantly single central (Figures 5 and 6). 
Research, Society and Development, v. 11, n. 2, e47111226019, 2022

(CC BY 4.0) | ISSN 2525-3409 | DOI: http://dx.doi.org/10.33448/rsd-v11i2.26019

Figure 2: Dog's left eye showing worsening in clinical symptoms seven days after the ophthalmic consultation: conjunctival congestion and increased episcleral vessels (*), hypopyon (white arrow) and hyphema (red arrow).

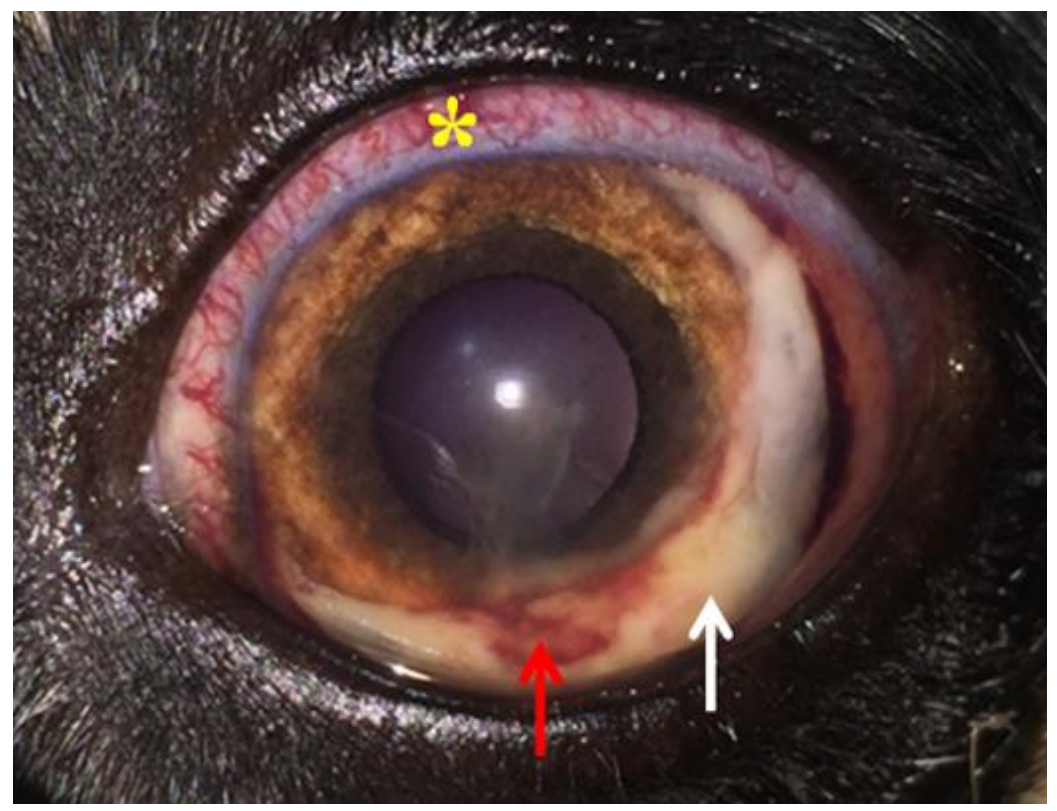

Fonte: Arquivo pessoal (2019).

Figure 3: Left eye of dog with conjunctival congestion and increased episcleral vessels $(*)$, posterior synechia (blue arrow) and neoformation in iris (red arrow).

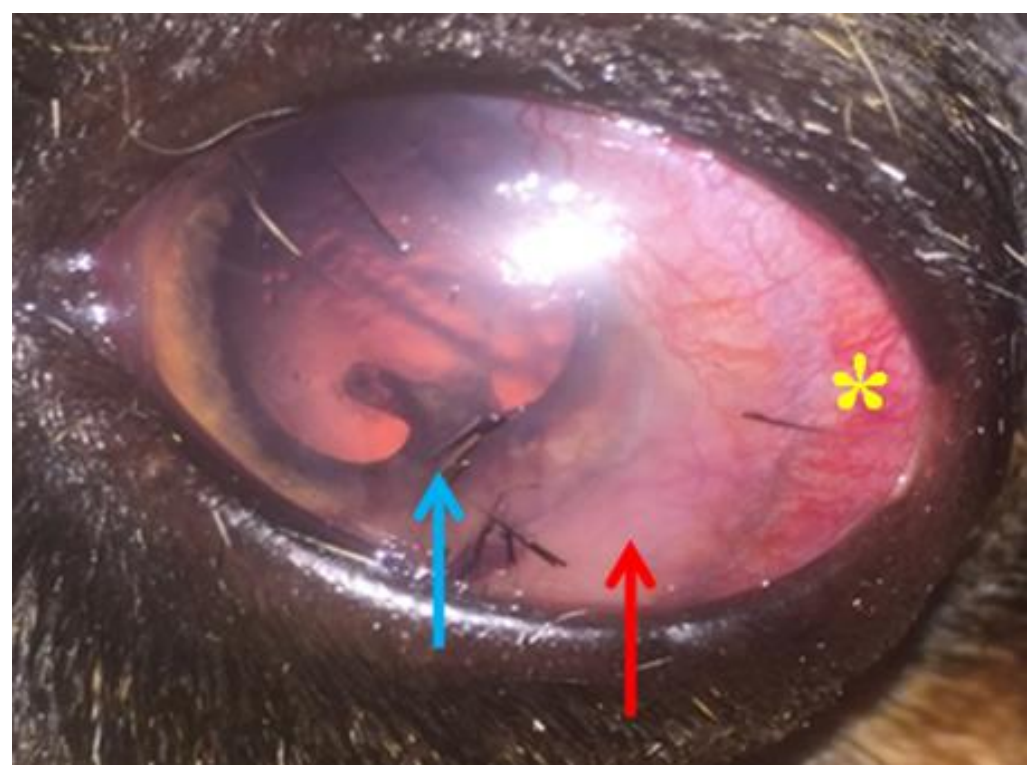

Fonte: Arquivo pessoal (2019). 
Figure 4: Ultrasonographic image of a dog's left eye, showing an oval image on the ciliary body, measuring $1.31 \mathrm{~cm} \times 0.51 \mathrm{~cm}$, with irregular contours (delimited by yellow and red asterisks).

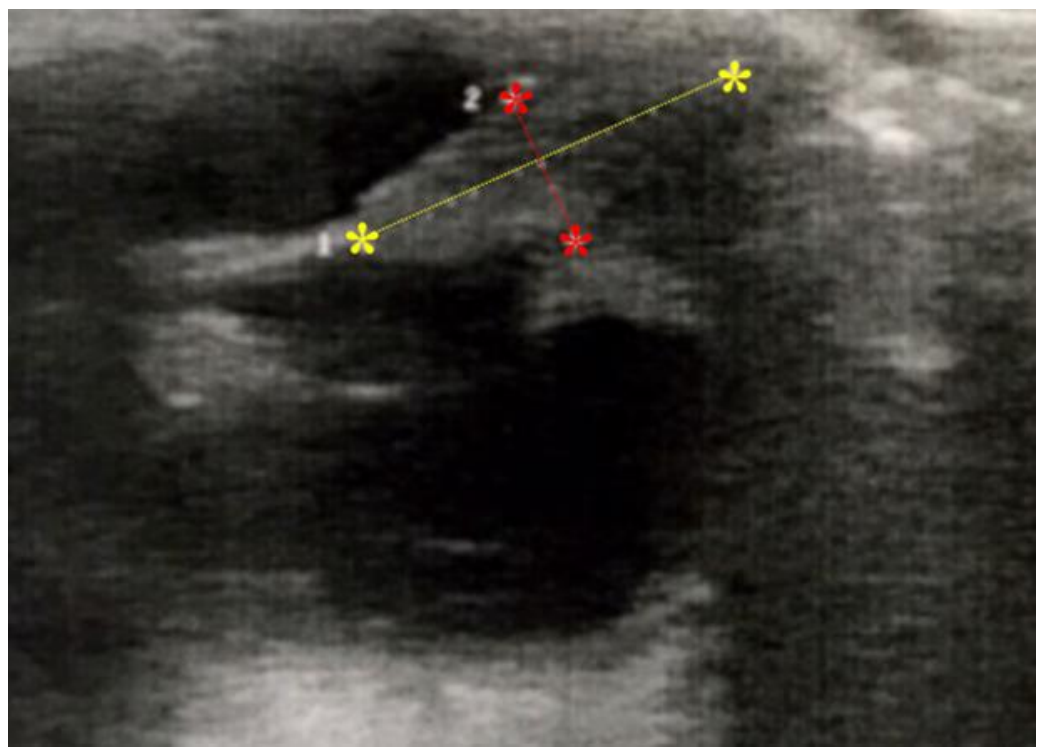

Fonte: Arquivo pessoal (2019).

Figure 5: Photomicrographs of a dog's left eyeball with large cell lymphoma. A: presence of proliferation of neoplastic cells starting in the uveal region (yellow asterisk), not invading the cornea (black asterisk), H.E., obj 2.5x. B: invasion of sclera neoplastic lymphocytes (yellow asterisk), H.E., obj 10x.

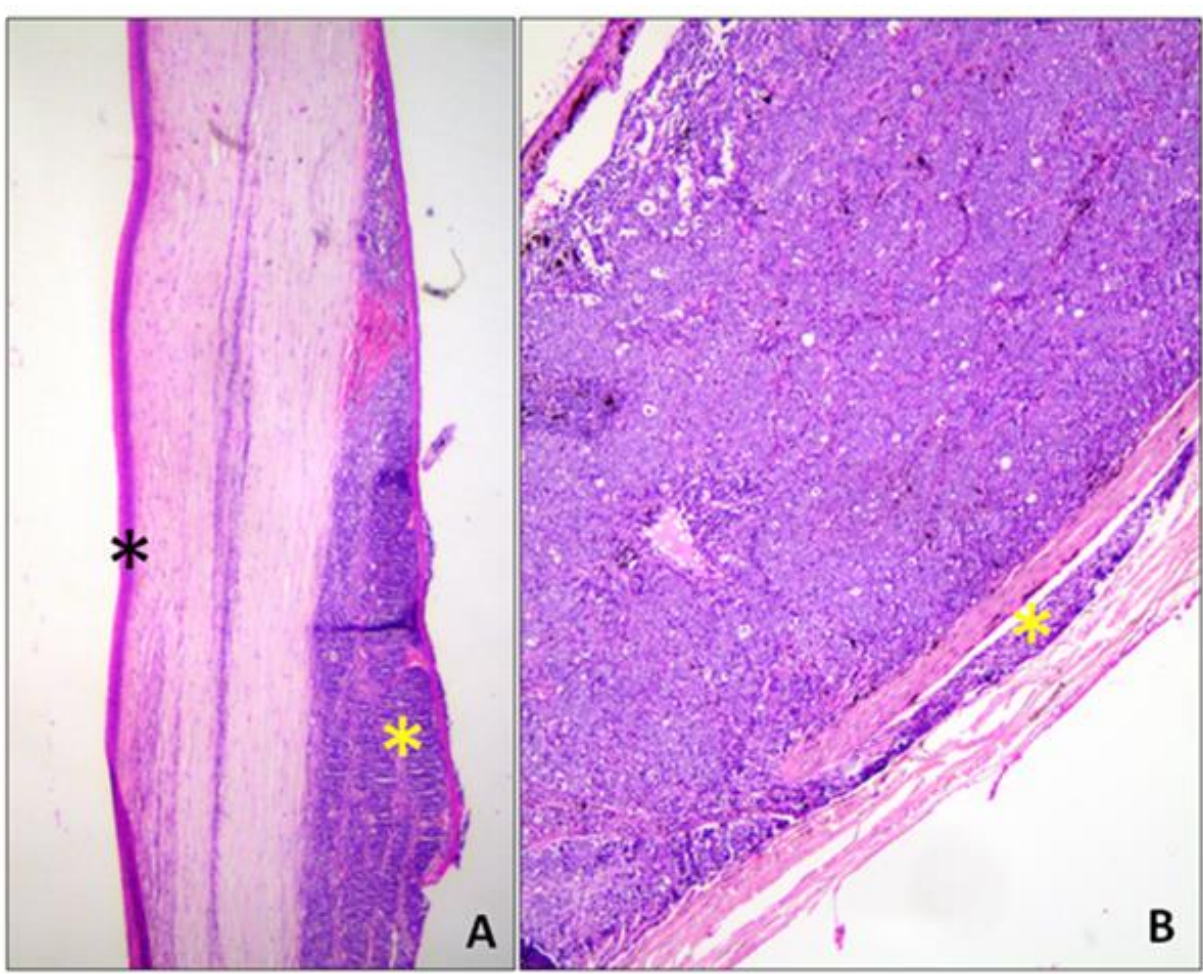

Fonte: Arquivo pessoal (2019). 
Figure 6: Photomicrographs of a dog's left eyeball with large cell lymphoma. A: presence of pycnotic nuclei (red arrow) interspersed with the proliferation of neoplastic lymphocytes, H.E., obj 20x. B: large lymphocytes, with vesicular nucleus, evident single nucleolus (red arrow) and scarce cytoplasm. Presence of mitosis figures (black arrow), H.E., obj 40x.

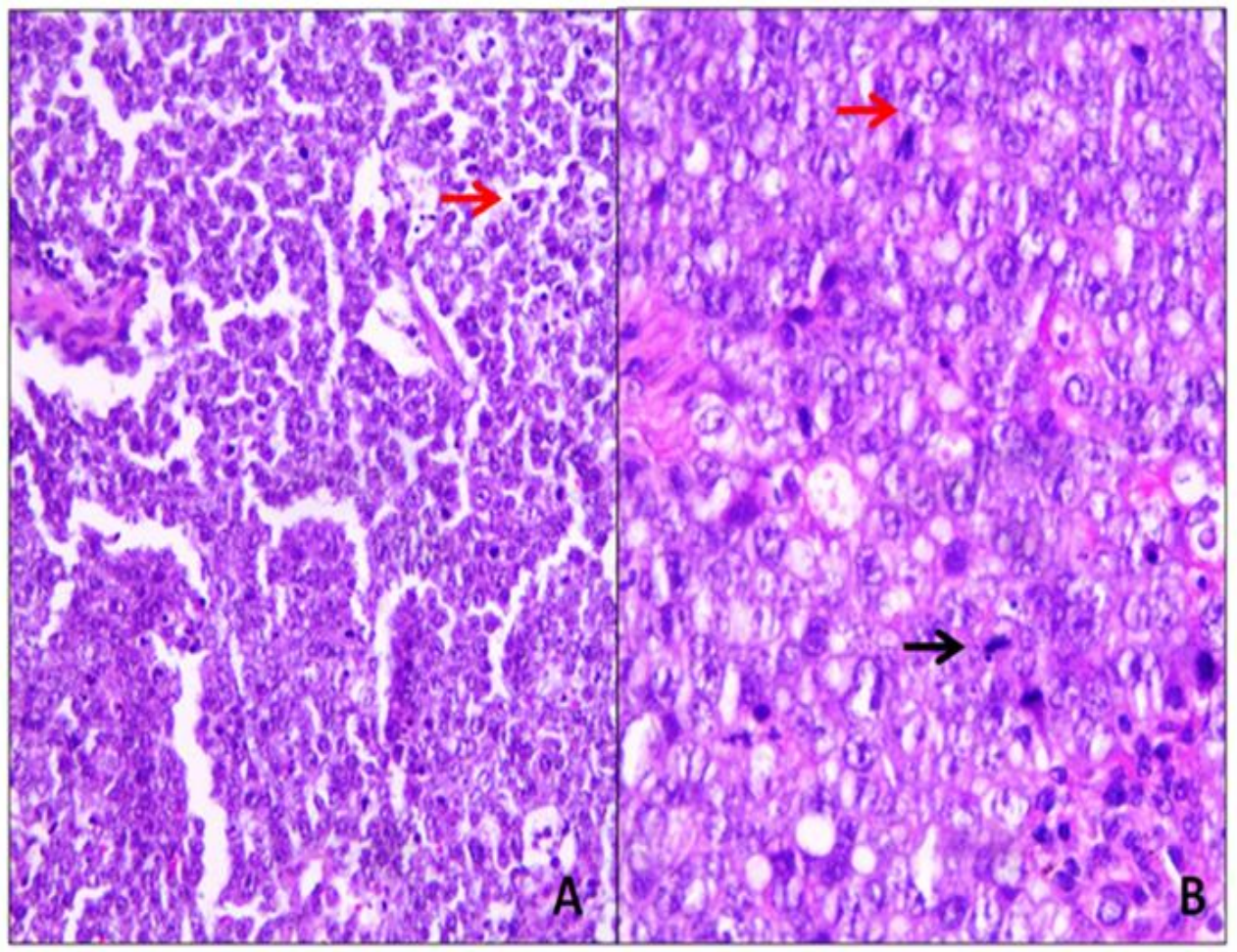

Fonte: Arquivo pessoal (2019).

In addition, the presence of discrete multifocal necrosis areas and 36 mitosis figures in ten high-magnification fields. Histopathological examination revealed large cell lymphoma in the left uveal tract. Two years after the surgical procedure, the patient is without signs of metastasis.

\section{Discussion}

According to Escanilla et al. (2012), Malho et al. (2013) and Oliveira et al. (2016), the uvea of dogs, as it is a highly vascularized tissue and does not have lymphatic vessels, becomes a common site of metastases from neoplastic lymphocytes disseminated by the hematogenous route, not coinciding with the primary occurrence of uveal lymphoma in the patient described. In a retrospective study by Wiggans et al. (2014), only seven dogs and two cats were diagnosed with primary intraocular or conjunctival lymphoma, over a period of 28 consecutive years, representing only $0.18 \%$ of all diagnoses of this neoplastic type. Thus, as the reports of primary lymphoma in the canine species are scarce in the scientific literature, the discussion becomes restricted.

The age of the described patient corroborated with the scientific descriptions (Dubielzig, 2002; Grahn et al., 2006; Hesse et al., 2015), that dogs of middle to advanced age are the most affected by intraocular neoplasms.

According to Conceição et al. (2010), Oriá et al. (2015) and Lanza et al. (2018), some cases of intraocular neoplasms are not diagnosed ante-mortem due to the asymptomatic presentation of the disease or the variety of non-specific clinical signs. Thus, the importance of complementary eye exams in the clinical routine is emphasized for early diagnosis and, consequently, not compromising conservative and surgical therapeutic options (Rodriguez et al., 2017; Moreira et al., 2018). Due to the high 
cost of more sophisticated diagnostic methods such as computed tomography and magnetic resonance imaging (Oriá et al., 2015), the diagnosis for the current case was based on the patient's clinical symptoms, measurement of intraocular pressure and ocular ultrasound, which provided consistent and reliable data for prognosis and therapeutic choice (Grahn et al., 2006; Rodriguez et al., 2017).

As for the clinical signs, in addition to those presented by the reported patient, Oliveira et al. (2016) also discussed the possibility of increase in submandibular lymph nodes, blepharospasm, photophobia, ocular sensitivity, exophthalmos, anterior and posterior uveitis unresponsive to treatment, panuveitis, discourse and anisocoria was also discussed. Furthermore, Escanilla et al. (2012) stated that the chronicity of symptoms can cause keratitis, lens dislocation, intra-retinal hemorrhage and displacement of the retina. In humans, primary intraocular lymphoma is also considered rare, with the retina, vitreous and optic nerve being the most affected structures, causing inflammatory uveitis that is difficult to trea (Cypel et al., 2007).

With regard to neoplastic progression, primary uveal lymphoma has shown rapid growth, worsening clinical symptoms, as described by Conceição et al. (2010) e Hesse et al. (2015). In this theme, it is worth mentioning that due to the variety of clinical signs, degree of malignancy and local invasiveness of this neoplasm, it must be included in the differential diagnosis of eye disorders that affect dogs.

Among the therapeutic options for intraocular lymphoma, chemotherapy and radiotherapy are included, as well as topical adjuvant medications to decrease intraocular pressure in cases of secondary uveitis (Labelle \& Labelle, 2013). In this context, Ota-Kuroki et al. (2013) reported that B-cell lymphomas have a better response to chemotherapy than T-cell lymphomas; moreover, low-grade lymphomas are less susceptible to treatment with chemotherapy than those of intermediate to high grade. In the reported patient, enucleation was the technique of choice, due to the tumor location in the uveal tract, which makes the prognosis unfavorable due to local sensitivity, visual loss and secondary glaucoma (Conceição et al., 2010; Oriá et al., 2015; Lanza et al., 2018). Furthermore, according to Oriá et al. (2015), intraocular neoplasms are responsible for $3.5 \%$ of cases of secondary glaucoma, which are not responsive to conventional topical treatments.

The recommendation of surgical treatment allowed a significant improvement in the quality of life of the reported patient (Martin et al., 2013) and avoided the occurrence of metastases in adjacent and systemic ocular tissues, despite Conceição et al. (2010) discoursed that primary ocular neoplasms demonstrate low metastatic potential. In this theme, the retrospective study carried out by Lanza et al. (2018), showed that dogs with primary lymphoma showed longer survival compared to those with concomitant systemic impairments; thus, the researchers suggested that some cases of primary lymphoma could have been effectively cured by enucleation surgery, which would increase the longevity of these patients.

The dog described in this study, despite not showing evidence of systemic metastases, had a longevity of two years, unlike the case of primary orbital lymphoma described by Aquino et al. (2000) in an 11-year-old Sheepdog, who died six months after the diagnosis, due to liver and gastrointestinal metastases.

In view of the unusual occurrence of primary uveal lymphoma in the canine species (Escanilla et al., 2012; Malho et al., 2013; Oliveira et al., 2016; Lanza et al., 2018), it is suggested that the diagnosed cases be described in the scientific literature, aiming at the dissemination of the proportion of cases, review data (race, age and sex), clinical symptoms, evolution of the condition, means of diagnosis used, staging, instituted therapies, characteristics histomorphological, survival time and prognosis of the affected, which can assist in the knowledge of the disease and, in the future, in the early diagnosis and treatment of other patients.

\section{Conclusion}

Based on the case described, it is admitted that, although uncommon, lymphoma can affect the uveal tract of dogs in a primary way, manifesting with rapid evolution and varied symptoms, which can directly compromise patient's quality of life, 
mainly due to loss of visual acuity. In addition, early diagnosis and correctly instituted treatment favor the quality of life and longevity of those affected. Thus, it is suggested the publication of future scientific articles on the subject, in addition to case reports, for dissemination and awareness of dog tutors and veterinarians.

\section{Acknowledgments}

Coordenação de Aperfeiçoamento de Pessoal de Nível Superior - Brasil (CAPES) and Universidade de Franca.

\section{References}

Aquino, S. M., Hamor, R. E., Valli, V. E., kitchell, B. E., Tuvev, S. S., Bailey, K. L. \& Ehrhart, E. J. (2000). Progression of an orbital T-cell rich B-cell lymphoma to a B-cell lymphoma in a dog. Veterinary Ophthalmology, 37(5): 465-469.

Carson, F. L \& Hladik, C. (2009). Histotechnology - a self instructional text. (3a ed.), ASCP Press, 400p.

Conceição, L. F., Ribeiro, A. P., Piso, D. Y. T. \& Laus, J. L. (2010). Considerations about ocular neoplasia of dogs and cats. Ciência Rural, 40(10):22352242 .

Cypel, M., Belfort Júnior, R., Moraes, N. \& and Muccioli, C. (2007). Linfoma intra-ocular primário de células tipo B: relato de caso. Arquivo Brasileiro de Oftalmologia, 70(4):709-712.

Dubielzig, R. R. (2002). Tumor of the eye. In: Meuten, DJ. Tumors in Domestic Animals, (4a ed.), Ames, p.739-754.

Escanilla, N., Leiva, M., Ordeix, L. \& Pena, T. (2012). Uveodermatologic lymphoma in two young related Portuguese water dogs. Veterinary. Ophthalmology, $15(5): 345-350$.

Gelatt, K. N., Gilger, B. C. \& Kem, T. J. (2013). Veterinary Ophthalmology (5a ed.), Wiley-Blackwell, 2260 p.

Grahn, B. H., Peiffer, R. L., Cullen, C. L. \& Haines, D. M. (2006). Classification of feline intraocular neoplasms based on morphology, histochemical staining, and immunohistochemical labeling. Veterinary Ophthalmology, 9(6):395-403.

Hesse, K. L., Fredo, G., Guimarães, L. L. B., Reis, M. O., Pigatto, J. A. T., Pavarini, S. P., Driemeier, D. \& Sonne, L. (2015). Neoplasmas oculares e de anexos em cães e gatos no Rio Grande do Sul: 265 casos (2009-2014). Pesquisa Veterinária Brasileira, 35(1):49-54.

Labelle, A. L. \& Labelle, P. (2013). Canine ocular neoplasia: a review. Veterinary Ophthalmology, 16(1):3-14.

Lanza, M. R., Musciano, A. R., Dubielzig, R. D. \& Durham, A. C. (2018). Clinical and pathological classification of canine intraocular lymphoma. Veterinary Ophthalmology, 21(2):167-173.

Machado, F. S., Iles, B., Sá, R. E., Araújo, D. D., Andrade, G. L., Arantes, A. R., Sousa, G. C., Monteiro, L. D., Oliveira, A. C. P., Santos, L. B. P \& Franco, M. S. C. R. (2021). Prospecção científica e tecnológica do uso de nanopartículas com alendronato de sódio no tratamento de câncer. Reserach, Society and Development, 10(12):1-10.

Maggs, D. J., Miller, P. E., Ofri, R. (2013). Slatter's Fundamentals of Veterinary Ophthalmology. (5a ed.), Elsevier, 506p.

Malho, P., Dunn, K., Donaldson, D., Dubielzig, R. R., Birand, Z. \& Starkey, M. (2013). Investigation of prognostic indicators for human uveal melanoma as biomarkers of canine uveal melanoma metastasis. Journal of Small Animal Practice, 54(11):584-593.

Martin, L. F. T., Rocha, E. M., Garcia, S. B. \& Paula, J. S. (2013). Topical Brazilian propolis improves corneal wound healing and inflammation in rats following alkali burns. BMC Complementary Alternative and Medicine, 13(1):1-7.

Moreira, M. V. L., Teixeira Neto, R. LAL., Langohr, I. M. \& Ecco, R. (2018). Prospective study of ocular and periocular diseases in animals: 188 cases. Pesquisa Veterinária Brasileira, 38(3):502-510.

Mota, L. P., Carvalho, M. R. R. A., Carvalho Neto, A. L., Ferreira, F. A. A., Poty, J. A. C., Pompeu, J. G. F., Rocha, M. M. L., Fé, R. C. M., Silva, L. E. B., Carvalho Neto, E. A., Silva, F. M. S., Oliveira, C. P. C., Rabelo, M. N., Marques, L. B. L. L \& Oliveira, G. M. S. (2121). Neoplasia de cabeça e pescoço: Principais causas e tratamentos. Research, Society and Development, 10(5):1-11, 2021.

Oliveira, M. C., Faleiro, R. D., Santos, C. C. A., Oliveira, G. F., Daoualibi, Y., Sonne, L., Brito, M. F. \& Ubiali, D. G. (2016). Linfoma de células T multicêntrico e ocular em equino. Revista Brasileira de Medicina Veterinária, 38(2):149-153.

Oriá, A. P., Estrela-Lima, A., Dórea Neto, F. A., Raposo, A. C. S., Bono, E. T. \& Monção-Silva, R. M. (2015). Principais neoplasias intraoculares em cães e gatos. Revista Investigação, 14(2):33-39.

Ota-Kuroki, J., Ragsdale, J. M., Bawa, B., Wakamatsu, N. \& Kuroki, K. (2013). Intraocular and periocular lymphoma in dogs and cats: a retrospective review of 21 cases (2001-2012). Veterinary Ophthalmology, 17(6):389-96.

Pereira, A. S., Shitsuka, D. M., Parreira, F. J., \& Shitsuka, R. (2018). Metodologia da Pesquisa Científica. Universidade Federal de Santa Maria. UFSM. https://repositorio.ufsm.br/bitstream/handle/1/15824/Lic_Computacao_Metodologia Pesquisa-Cientifica.pdf?sequence=1 . 
Research, Society and Development, v. 11, n. 2, e47111226019, 2022

(CC BY 4.0) | ISSN 2525-3409 | DOI: http://dx.doi.org/10.33448/rsd-v11i2.26019

Rodriguez, E. A. K., Perlmann, E., Abranches, L. S., Pecora, R., Suhett, L. \& Goes, A. C. A. (2017). Linfoma intravascular uveal em um cão. Revista Científica de Medicina Veterinária - Pequenos Animais e Animais de Estimação, 15(46):34-37.

Wiggans, K. T., Skorupski, K. A., Reilly, C. M. \& Allstadt, S. D. (2014). Presumed solitary intraocular or conjunctival lymphoma in dogs and cats: 9 cases (1985-2013). Journal of the American Veterinary, 244(4):460-470. 